\title{
The problem of integrated model of freedom in global world of philosophical science
}

\author{
Gaukhar Tasbergenova - Galiya Begembetova - Aizada Nussupova - \\ Adalyat Yussupova - Saule Medeubayeva
}

DOI: $10.18355 /$ XL.2021.14.03.17

\begin{abstract}
The article is devoted to the analysis of the philosophical heritage related to the problems of democracy and freedom. The search for new ideas about the phenomena of democracy, freedom, and personal development in various perspectives is carried out. We prove that the components of democracy include freedom, justice, and equality. Our article also shows that for a modern person, democracy is not conceived of without freedom. The position of the fundamental importance of freedom as the highest value for a worthy existence of the individual has also been further developed. It is established that the majority of people are ready to fight for the right to be free by all available means. For them, being free is a vital necessity. The life of modern society has several regularities, and one of them is the need to create conditions that involve a conscious choice of democratic values, the ideal of personal freedom, and creative development. The necessity of creating a model for the development of a free and harmonious personality is established. The article analyzes the key concepts of the essence of freedom in the history of philosophy. The understanding of Western European philosophical doctrines and systems allowed us to identify the peculiarities of understanding the problem of freedom in European philosophy and also to conclude that this understanding leaves for the individual the right to break out of the fetters of necessity. In the course of our study, we reveal the trajectory of the movement of an abstractly taken individual along the path of its ascent to freedom.
\end{abstract}

Key words: Western philosophy, freedom, philosophical science, heritage

\section{Introduction}

Freedom is the universal culture of the subjective series, which fixes the possibility of activity and behavior in the absence of external goal-setting. In the historical context of European culture, the dominant aspect is freedom, which is articulated in the classical philosophical tradition as freedom of will. (Aristotle, 1983) Today, the problem of freedom is particularly acute in the face of all mankind. We make claims to the state; we demand freedom of speech, freedom of action. We demand a new, better life, without understanding what this life should be. What is individual existence in freedom? What does it entail? We will turn to the history of philosophical thought to find answers.

One of the most pressing philosophical problems is freedom. It has been scrutinized in the history of philosophy, yet, this topic still needs deep philosophical research, not only by individual outstanding thinkers but also entire philosophical trends. This is because freedom is one of the innumerable, truly philosophical problems that force human thought to work at full capacity.

Also, the problem of freedom is central to the modern process of socio-cultural transformation of Russian society. (Pushkarev et al., 2019) This process is characterized by a sharp transition from the lack of human freedom in a totalitarian state to freedom in a market economy, to the freedom of democracy, to the formation of civil society, to the freedom of the spirit. In times of rapid and widespread transformation, freedom becomes the subject of debates and academic discussions. In the context of the disintegration of "rigid" social ties, when the influence of traditions that determine the construction of interpersonal ties, socio-cultural and personal 
identities weakens, the problem of individual freedom and individual situation comes to the fore, within the framework of which new values, traditions, and life-meaning guidelines are formed.

The problem of individual freedom is constantly intertwined with the question of the limits of this freedom. The question about the possibility of personal freedom, about its existence, can be answered: it is everywhere and always where there is an "I", a person who not only makes a choice but also constructs it and is aware of his responsibility. Responsibility as the reverse side of freedom is not an easy burden. Not everyone is ready to take this burden on themselves, so quite often we see "flight" from freedom, from oneself, conformism, dispersion of the individual. The problematic nature of man coincides with the complication of the space-time continuum: socio-cultural values and the laws of continuity are changing - the past, present, and future are not the same in time.

The situation in which modern man finds himself is a complicated one. The old norms of behavior, which somehow gave an answer to the question of how to live, what is good and what is evil, what a person should be, how to communicate with his own kind are gradually waning. The ready-made schemes in which a person could in most cases fit, no longer "work." Today, a person has to find a new meaning, new values and new ideals associated with a free definition of what the meaning of life is and what moral creed one should live by. Based on this, the situational analysis of individual freedom is relevant.

Freedom as a category of philosophical knowledge is a complex concept, the content of which expands with the knowledge of the self-organizing world. In social philosophy, the theme of freedom is cross-cutting and is reflected in many representatives of philosophical thought from antiquity to the present day, regardless of their worldview positions. The idea of freedom has gone through a long and difficult path of development. Historically, freedom has been understood from the earliest times as the opposite of necessity. Since then, up to the present day, freedom has been analyzed in conjunction with necessity. (Robinson, 2016; Berofsky, 2017) It is difficult to find the most optimal ways to deal with the question of freedom given the challenges that our societies face in the present. The current stage of the philosophical vision of the problem of individual freedom and democracy is conditioned by all the previous development of European philosophical thought. The problems that are being investigated have been verbalized in one way or another as questions about whether a person is able to "advance" himself and his life remain answered only inconclusively. Can he be the master of his fate? (Rousseau, 1998); what is his attitude to freedom and necessity? (Kant, 1994, vol.8); what does democracy mean for a human person?

Evolutionary development manifests itself in the measure of human freedom and in the ability of a person to master this freedom. Freedom requires a person to be an individual, to assert himself as a person. The theme of freedom has always been fundamental for both classical and modern philosophy because it belongs to the "eternal" problems of human existence (Berdyaev, 1989; Walla, 1989; Fromm, 1989; Engels, 1961). But, despite its common usage, the study of democracy and freedom acquired a special sound and sharpness at the turn of the $20^{\text {th }}$ and $21^{\text {st }}$ centuries (Demokratiya: anthologiya, 2005; Huntington, 1994).

\section{Discussion}

In this context, the need for special attention to the theoretical and methodological foundations of the study of the phenomenon of individual freedom and the democratic social environment that contributes to the formation of appropriate values is brought to the fore. (Beetham, 1999) The purpose of this research is to analyze the classical philosophical heritage on the problems of democracy and human freedom, to

XLinguae, Volume 14 Issue 3, June 2021, ISSN 1337-8384, eISSN 2453-711X 
comprehend the modern vision of these problems, and to anticipate the constructive possibilities of creating a model for the development of a free and harmonious personality in modern society.

The study used such general scientific methods as analysis, systematization, forecasting, as well as the comparative-historical method and special methods (survey, questionnaire (modified questionnaire)). The history of the study of the problem of freedom is divided into a number of periods, each of which represented an important step in the development of its understanding. (Adorno, 2006) Philosophy has investigated this problem because philosophy itself arises as a free type of thinking, as a worldview justification of a person's right to "dissimilarity," to freedom. The initial period of thinking about freedom dates back to the times of antiquity. Democritus, for example, declared: "Everything in this world happens out of necessity, and everything has its cause, there is no chance, and if so, then there is no freedom in the life of man because everything that a man does, he does out of necessity and everything that happens to him, has a necessity and a reason again." (Kant, 1994.) Thus, he recognized the existence of freedom associated with understanding it as the independence of human will and action from any conditions, as "freedom from": from fate, from political despotism, from natural dependence, norms, etc. The recognition of the fullness of free will inevitably meant a diminution of the divine omnipotence and the need to revise the entire picture of the world, built on ideal principles. But it was not until the $19^{\text {th }}$ century that philosophy finally abandoned the idea of God. However, the first successful bourgeois revolutions took place already in the $17^{\text {th }}$ century. The foundations of civil society and legal democratic states were formed. Thomas Hobbes developed the position of "innate egoism," emphasizing the immutability of "human nature" and utility as a defining moral principle. The mutual restriction of people's egoism on the basis of the natural law of self-preservation and the state created on a contractual basis can put an end to the "war of all against all" and the pre-moral state of man. The social contract and the state allow us to give the concepts of good and evil a universally valid character: the state, by establishing laws that are uniform for all, introduces the interests and aspirations of people within certain boundaries that best meet their common interest, which is expressed in support of peace and self-preservation. At the heart of the structure of the state and its laws should be the highest, natural moral law, for which people have united in the state - this is the civil welfare, the well-being of the people. A free person is one who is not prevented from doing what he wants because he is physically and mentally able to do it. (Hobbes, 1991)

In the European space, philosophers stipulate that human nature and freedom, which, in turn, derive the fundamental rights of a citizen, regardless of existing state power and which is for her inviolable. D. S. Mill's treatise On liberty is trying to prove that the only justification for interfering with freedom of action of any human being's self - defense is the prevention of harm that can be inflicted on others. Mill defends the need for freedom of opinion and freedom of discussion. The value of a State is determined by the value of its citizens.

Immanuel Kant put forward an approach according to which the position of a person in society reasonably combines freedom and necessity, that is, a society in which maximum freedom under external laws is combined with an irresistible compulsion, i.e., a completely fair civil order, should be the highest task of nature for the human race. Kant's theory of freedom is based on the dualism of the sensory and supersensible worlds: the subject is divided into an empirical subject, and an intelligible subject, necessity and freedom are fully divided between them. Man is not only an empirical individual but also a transcendental subject, and in this capacity, he is free as a rational, moral being. Kant distinguishes between internal (moral) freedom and external, legal freedom, which can and should be ensured by the corresponding state structure. According to Kant, law is by its very nature republican. Republicanism 
is the essence of the legal system. Kant also develops the problem of freedom in an international context. (Kant, 1994)

Thus, in the $18^{\text {th }}$ century and in the first half of the $19^{\text {th }}$ century, bourgeois rights and freedoms were strengthened. The liberal doctrine of the natural rights of man to life, liberty, and property came to the fore, requiring society to grant the individual maximum freedom for self-realization. The natural and only limitation of such freedom was the freedom of another individual. Of interest are also the views on the freedom of Friedrich Engels. In his work "Anti-Duhring," the concept of "freedom as a conscious necessity" is most fully formulated. Such an understanding of freedom is quite suitable for explaining the nature of human freedom in a society that is forced to take into account both the laws of society and the interests of other people. Engels believes that the history of humanity represents the movement of man and humanity towards freedom (Engels, 1961). This concept became the basis for several ideologies characteristic of the late nineteenth and twentieth centuries.

Erich Fromm, in his work "Escape from Freedom," shows that the achievement of freedom by a person as a result of social progress can have very unexpected consequences for him at first glance. A sense of powerlessness and anxiety overcomes a person of modern society. E. Fromm answers the question as follows: "...What is freedom for a modern person? He became free from the external shackles that prevent him from acting in accordance with his own thoughts and desires. He would be free to act at will if he knew what he wanted, what he thought and felt. But he doesn't know that; he adapts to the anonymous power and assimilates the "I" that is not his essence. And the more he does this, the more helpless he feels, the more he has to adapt..." (Fromm, 1989: 130,).

The way out of this situation can be found in the realization of the ideal of positive freedom, as it is seen by the Russian philosopher N. A. Berdyaev in his work The Meaning of Creativity: “... Freedom is not the realm of arbitrariness and chance, in contrast to the realm of regularity and necessity... Freedom is the power to create from nothing, the power of the spirit to create not from the natural world, but from itself. Freedom in its positive expression and affirmation is creativity..." (Berdyaev, 1989: 89).

This understanding of freedom contributed to the formation of man as a social and political being. Such a philosophically "basic" definition was a negative understanding of freedom. Plato did not deny the existence of freedom. He put the question differently: It is not about whether a person can be free, but whether he needs freedom, for what and for what purposes can he use it? As a result, he comes to the conclusion that freedom can bring nothing but harm to a person, because independent of laws and traditions, a person can fall into turmoil, rebellion. Plato recognizes the existence of freedom in the world and argues that freedom is the prerogative of the state. But it is not necessary for a person; it is dangerous. He was the first to consider freedom as "freedom for." (Plato, 1994) It was only after two and a half thousand years that another answer to his question was provided.

In the early Middle Ages, a new understanding of freedom emerged. Its interpretation is to overcome religious fatalism. Everything in this world is from God. This means that the sinfulness of a person depends on the will of God. Therefore, the thought of Origen, Augustine, and Thomas Aquinas worked in the direction of getting God out of Harm's way. They have forever inextricably linked the freedom of man with his responsibility. (Plato, 1994)

Augustine argued that the human world is overflowing with evil, but that man himself, his free will, is to blame. God, filled with mercy to man, his creation, gave him freedom. A person is free to choose his own life path, whether it is righteous or sinful, but then the responsibility for his actions, carried out on the basis of free will, should not be borne by God, but by the person himself. It turns out that freedom is a

XLinguae, Volume 14 Issue 3, June 2021, ISSN 1337-8384, eISSN 2453-711X 
personal choice of a human person, but in addition to freedom, a person receives a huge burden of responsibility. (Chappell, 1995)

In Pico della Mirandola's works, the understanding of freedom as choice is at the heart of his reflections on man. God has not assigned man a place in the hierarchy of existence, he says in his famous "Speech on the Dignity of Man": "We do not give you, O Adam, a certain place, nor a particular image, nor a special duty, so that you may have both a place, a person, and a duty according to your own will, according to your will and your decision. The image of other creatures is determined within the limits of the laws we have established. You, who are not constrained by any limits, will determine your image according to your decision, to which I leave you." (Robinson, 2016: 120)

Man is placed in the center of the world. He has no special nature, no mortality, no immortality; he must form himself as a "free and glorious master." Both the appearance and the place of a person in the hierarchy of entities can and should be solely the result of his own free, and therefore responsible, choice. Thus, Mirandola came close to an important problem of the present time - the problem of human selfactualization.

The age of Enlightenment gave rise to a new understanding of freedom (quite in the spirit of the times), based on the recognition of the power of human reason and knowledge. It was proposed by Benedict Spinoza. In the world of universal necessity, man can nevertheless push the limits of his freedom, for it is the result of the knowledge of necessity. "Freedom is a recognized necessity." (Kant, 1994) Although Spinoza's concept was generally contemplative, unlike the activity of freedom among Renaissance thinkers, his idea of the connection between freedom and knowledge formed another aspect of the problem of freedom. (Gritsanov, 2001)

In a certain sense, Kant revives Plato's approach. There is no freedom, he says, everything in the world is rigidly determined. He explains: but this is the case in the intelligible world. Man lives in two worlds. On the one hand, he is a phenomenon, a cell of the sensory world that exists according to its laws, sometimes far from humanity. But on the other hand, he is a noumenon, a supersensible being, subject to the ideal. A person has two characters: empirical, instilled by the environment, and noumenal, intelligible, as if inherent in him from within. The approach proposed by Augustine at the time found its continuation in various directions of subjectivist philosophy. Freedom, understood as a choice, significantly expands the limits of human capabilities based on free will.

A significant contribution to the new understanding of freedom was made by existential philosophy, for which the problem of freedom is the key one. In the understanding of existentialism, freedom is an integral, immanent characteristic of a person, his generic trait. As Jean Paul Sartre said, "a man is free or he is not a man ... Man is doomed to be free." (Fedorova, 2009: 17) Freedom is not a good thing for a person, but a heavy burden, and this burden is due to the responsibility that we bear for our free choice. Here we see a similarity with the interpretation of freedom in Aurelius Augustine. (Gritsanov, 2001)

What is freedom? What does a person need it for? In the end, the answer was found: A person needs freedom for creativity, understood in the broadest sense. Freedom is a prerequisite for creativity as a creation of fundamental novelty. N. A. Berdyaev played a special role in the analysis of freedom. Freedom for him is not just a characteristic of human existence. It ontologizes freedom. Being a religious philosopher, N. A. Berdyaev, nevertheless, puts freedom before God, that is, before the beginning of the act of creation. In order to create, man or God must have freedom, inner freedom. If God created everything in this world, it means that he already, as the creator, had freedom. If freedom did not exist before the beginning of Creation, then Creation itself would not exist. Consequently, N. A. Berdyaev concludes, "freedom is the baseless basis of being." (Berdyaev, 1989: 59) N. A. 
Berdyaev has another "seditious" point - it is about the godlike nature of man. God did not and could not create man in his outward appearance. The God-likeness of man is not external but internal. The godlike nature of man lies in his ability to be a creator. It is the creative essence that makes a person related to God. It is creativity that gives meaning to human existence. Based on this, freedom is independence. It is the possibility of choice, which assumes the responsibility of a person for his choice, and which is closely linked and conditioned by the level of knowledge of a person and society.

Understanding Western European and national philosophical doctrines and systems allowed us to identify the peculiarities of understanding the problem of freedom in European philosophy and conclude that this understanding leaves the individual the right to break out of the fetters of necessity. We see that for many centuries philosophers have presented to the world manifestos of a liberating ideology, but these popular announcements have never been accepted by mankind. But why? (Montesquieu, 1997)

Globalism has brought new challenges. The problem of terrorism has become more acute. Terrorist attacks violate the interests, sovereignty, and national feelings, as well as the moral principles of certain peoples and ethnic groups. And in the face of a common threat, unity and standing up for one's rights and freedoms are more important than detachment and hostility. Therefore, there is a need to create conditions that should lead to the birth of new values - social, ethical, spiritual, which will form the cultural atmosphere of the future. But in order for this transformation to become a reality, not only material costs are necessary, but also the restructuring of the principles on which modern culture is based.

To do this, the following conditions must be met:

1) the replacement of standardization with diversity and pluralism, which will be caused by new types of production, the structure of consumption (according to the theory of the development of reasonable needs), different forms of political behavior, the coexistence of different religious systems, etc.;

2) promoting not only centralization, but also decentralization of cultural ties and relations, which will reduce the importance of dividing the world into a developed center and a backward periphery (peripheral regions can also become centers of culture, science, and education);

3) broad informatization of society, which will lead to the fall of the status of bureaucracy and social hierarchy (the vertical distribution of society will be actively replaced by horizontal interaction between people);

4) the transformation of a person into the main social value.

In light of the current situation, a number of issues have become particularly relevant. Has the concept of freedom and democracy changed for the individual? What is valuable for a modern person? What does he need? What are his life values? In order to study the ideas of the modern young generation about democracy, freedom, as well as the attitude to values and ideals, a study was conducted. (Fedorova, 2009) The open-ended questionnaire included a list of relevant questions. The study was conducted at the Al Farabi University. It was attended by 957 students of the second, third, and fourth years (average age - from 19 to 21 years). The sample was formed from students studying "Philosophy" as their major. For the vast majority of respondents $(87 \%)$, democracy is primarily freedom in all its manifestations. For $13 \%$, democracy is associated with equality. (see table 1) That justice is an integral part of the democratic structure of society-this was stated by $90 \%$ of respondents.

XLinguae, Volume 14 Issue 3, June 2021, ISSN 1337-8384, eISSN 2453-711X 


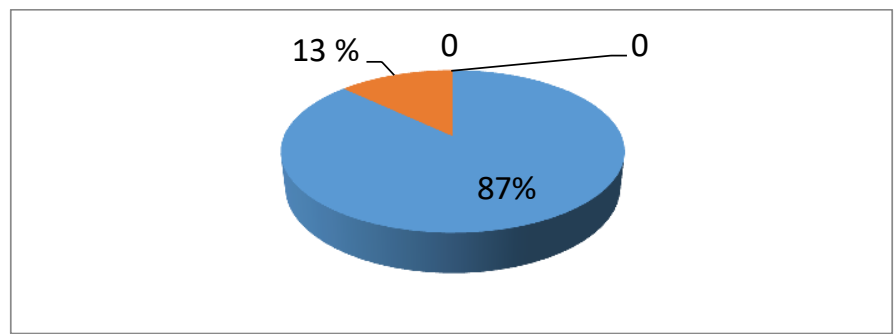

Table 1: Equality, Justice and Democracy (Uzbek, 2007)

The desire to defend their ideals and beliefs in any form (up to physical) was expressed by $68 \%$ of the subjects. All kinds of restrictions (movement, loss of rights, etc.) are perceived acutely and are categorically rejected by $93 \%$ of respondents.

Freedom for a modern student is primarily about opportunities, equal conditions for development, and the decent existence of the region's entire population. Almost 33\% of respondents are very willing to address the issue of faith, $43 \%$ of them emphasize that they support the revival of traditions. $10 \%$ of respondents called themselves atheists but noted that they are tolerant of believers. The remaining $14 \%$ experienced difficulties answering the question. (Table 2) (Uzbek, 2007)

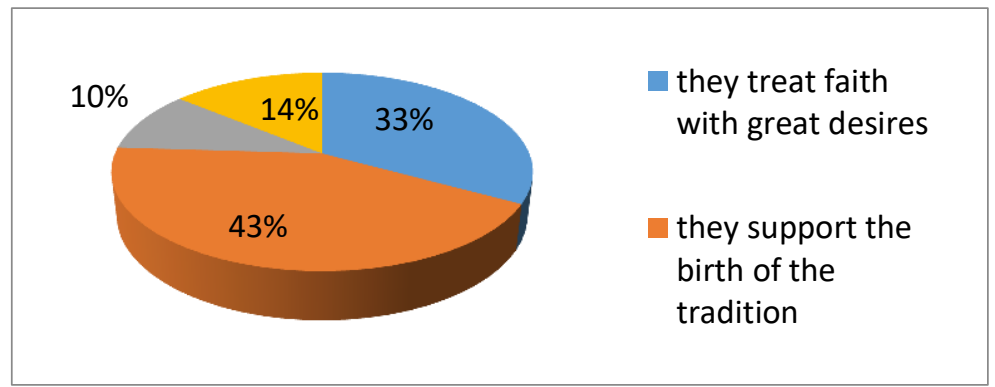

Table 2: Talking about one's religion/faith (Uzbek, 2007)

It should be noted that the students demonstrated a fairly high level of knowledge on the cultural traditions of the ethnic groups of their region. Self-realization is associated with the presence of democracy in almost $80 \%$ of respondents. The desire for changes in the cultural sphere was expressed by $76 \%$ of respondents.

\section{Conclusion}

Our modernity has preserved the continuity of the idea of freedom and the direction of philosophical thought in solving this problem posed by the nineteenth century - the search for supports for the free existence of man in the world. The Western ideal of a person in the modern sense is a self-valuable person. At the same time, the individualist is perceived in full accordance with the Christian doctrine of freedom of the spirit and freedom of choice of moral values. But perhaps, in light of the recent radical world transformations, this ideal may change. In the course of the study, we have demonstrated that for a modern person, democracy is not conceived without freedom. (cf.: Fromm, 1989)

Freedom is something that most people are willing to fight for in any way they can. Being free is a vital necessity. In the context of social uncertainty, compensatory features such as human dignity, civic responsibility, social justice and cultural tolerance acquire a special meaning. It is established that a society that cultivates a creative attitude to life, involving the conscious improvement of each person, turning 
him into a complete personality, is very attractive for every human person. (Engels, 1961) Social progress is made possible by combining personal potentials into a harmonious whole. Therefore, it is natural for modern society to create conditions that presuppose a conscious choice of democratic values, the ideal of personal freedom, and creative development. The development of a model for the development of a harmonious free personality is the prospect of further scientific research.

\section{Bibliographic references}

ADORNO, T.W. 2006. History and freedom: lectures 1964-1965. New York: Polity. ARISTOTLE. 1937. Athenian Polity. State structure of the Athenians. Moscow: State Socio-economic Publishing House.

ARISTOTLE. 1983. Politika. Essays, Vol. 4. Moscow: Mysl, pp. 375-644.

BEETHAM, D. 1999. Democracy and human rights (Vol. 249). Cambridge: Polity Press.

BERDYAEV, N.A. 1989. Smysl tvorchestva. In: Filosofiya svobody. The meaning of creativity. Moscow: Pravda, pp. 369-370.

BEROFSKY, B. 2017. Freedom from Necessity: the metaphysical basis of responsibility (Vol. 6). New York: Taylor \& Francis.

CHAPPELL, T. 1995. Aristotle and Augustine on freedom: two theories of freedom, voluntary action and akrasia. London: Springer.

ENGELS, F. 1961. Anti-Düring. In: Marx K. - Engels F., Essays. 2nd ed. Moscow: Gospolitizdat, Vol. 20, pp. 16-338.

FEDOROVA, E.V. 2009. Imperial Rome in persons. Moscow: Moscow University Press.

FROMM, E. 1989. Flight from freedom. A man for himself. Moscow: Progress.

GRITSANOV, A.A. (ed.). 2001. World Encyclopedia: philosophy. Moscow: AST; Minsk: Harvest; Sovremennyj literator.

HOBBES, T. 1991. Leviathan, or Matter, form and power of the state of the Church and civil. In: Essays, 2 volumes. Moscow: Mysl, Vol. 2, pp. 3-545.

HOBBES, T. 1989. Osnovy filosofii, Chapter 3. O grazhdane. In: Essays, 2 Volumes. Moscow: Mysl, vol. 1, pp. 270-506.

HUNTINGTON, S. 1994. Clash of Civilizations. New York: Palgrave Macmillan, pp. 34-38.

KANT, I. 1994. The idea of universal history in the world-civil plan. In: Essays, 8 vols. Moscow: Choro, Vol. 8, pp. 12-28.

MONTESQUIEU, S.L. 1997. On the spirit of Laws. In: Anthology of World Political Thought, 5 vols. Foreign Political Thought: Origins and Evolution. Moscow: Mysl, vol. $1 . \quad$ Available online: http://www.novsu.ru/npe/files/um/1412/bg/shell/arh/antolog/1.htm Interpresservice; Book House.

SALNIKOVA I. G.2000. Large illustrated dictionary of foreign words: 17,000 words. Moscow: AST: Astrel: Russian Dictionaries.

O. PROTSENKO. 2005. Demokratiya: anthologiya. Kiev: Smoloskip.

KUZMIN S. V. 2001. The latest philosophical dictionary. 2nd ed. Minsk:

PLATO. 1994. State. In: Collected works, 4 volumes. Moscow: Mysl, Vol. 3, pp. 79420.

PUSHKAREV, S. - BANNES, P. - RIASANOVSKY, N.V. 2019. Self-government and Freedom in Russia. London: Routledge.

ROBINSON, J. 2016. Freedom and necessity: an introduction to the study of society. London: Routledge.

ROUSSEAU, J.J. 1998. About the social contract, or the principles of political law. In: About the Social Contract. Trektaty. Moscow: Kanon-press; Kuchkovo field, pp. 70-213.

XLinguae, Volume 14 Issue 3, June 2021, ISSN 1337-8384, eISSN 2453-711X 
UTCHENKO, S.L. 1986. Cicero and his time. 2nd ed. Moscow: Mysl.

UZBEK, K.M. 2007. Mathematical heritage of Hellas. Donetsk: Multipress.

WALLA, L. 1989. About free will. To Bishop Garcia of Ileria. In: On the True and

False Good. About freedom of will. Moscow: Nauka, pp. 267-290.

Words: 4917

Characters: 30603 (17,00 standard pages)

Tasbergenova Gaukhar

Kazakh national conservatory named after Kurmangazy, 050000, Kazakhstan, Almaty

86 Abylai-Khan avenue

Kazakhstan

bislauka@mail.ru

Assoc. prof. Begembetova Galiya

vice-rector for research and international cooperation,

Kazakh national conservatory named after Kurmangazy

86 Abylai-Khan avenue

050000, Almaty

Kazakhstan

nurzhanzhan@mail.ru

Assoc. prof. Nussupova Aizada

Kazakh National Conservatory after Kurmangazy

Abylay khan avenue, 86

050000, Almaty

Kazakhstan

Yussupova Adalyat

Kazakh national conservatory named after Kurmangazy

050000, Kazakhstan, Almaty

86 Abylai-Khan avenue

Kazakhstan

prof. Medeubayeva Saule

Kazakh National conservatory named after Kurmangazy

Abylay khan avenue, 86

050000, Almaty

Kazakhstan 